\title{
Перспективы использования дикорастущих видов рода Paeonia L. в селекционной работе
}

\section{Prospects for the use of wild species of the genus Paeonia L. in breeding}

\author{
Успенская М. С., Мурашев В. В. \\ Uspenskaya M. S., Murashev V. V. \\ Ботанический сад биологического факультета Московского государственного университета им. М. В. Ломоносова, г. Мо- \\ сква, Россия. E-mail: ms-uspenskaya@yandex.ru
}

Botanical garden of biological faculty Moscow State University n. a. M. V. Lomonosov, Moscow, Russia

\begin{abstract}
Peферат. Дикие пионы представляют большую ценность для селекционной практики, особенно, при получении сортов раннего цветения. Дикорастущие виды - это исходный материал для получения отдельных генов, которые могут существенно улучшить сорта, например, повысить их декоративность, устойчивость к заболеваниям. Для этого из коллекционного фонда ботанического сада биологического факультета Московского государственного университета им. М. В. Ломоносова выделены наиболее перспективные для скрещивания виды: P. lactiflora, P. tenuifolia, P. anomala, P. mlokosewitchii. Их используют как для озеленения территории, так и на срезку. В ходе длительной работы были созданы новые сорта пионов. Время от скрещивания родительской пары до регистрации нового сорта пионов составляет, как правило, 10-15 лет.
\end{abstract}

Ключевые слова. Дикорастущие виды пионов, исследование морфогенеза, разработка технологии возделывания, селекция, создание коллекций.

Summary. Wild peonies are of great value for breeding practices, especially in obtaining varieties of early flowering. Wild species is the starting material for individual genes that can significantly improve varieties, for example, to increase their decorative, disease resistance. For this purpose, the most promising donors for crossing on a complex of economic and valuable features are allocated from the collection Fund. They are used for landscaping and cutting. The creation of a new variety of peonies is a complex process that includes a number of stages (development of a model of the future variety, selection of pairs for crossing, cultivation of seedlings, their study, reproduction of a new variety). The final stage is the preparation of a package of documents on the recognition of the rights to the variety and its transfer to the State service for the protection of plant varieties. From crossing the parent pair to the registration of a new variety of peonies is usually 10-15 years.

Key words. Creation of collections, development of cultivation technology, research of morphogenesis; selection, wild species of peonies.

Одним из основных направлений деятельности ботанических садов является изучение и сохранение биоразнообразия редких и полезных растений в условиях интродукции. Особый интерес представляет проведение подобных исследований в условиях резко континентального климата. А неустойчивые климатические условия Центральных районов нечерноземной зоны и суровые зимы лесостепной зоны Западной Сибири позволяют использовать данные регионы в качестве уникальных полигонов для изучения адаптационных возможностей родовых комплексов декоративных и других полезных растений. В связи с изменением тенденций в ландшафтном дизайне, особой популярностью стали пользоваться различные дикорастущие декоративные растения, многие из которых послужили исходными формами для выведения современных сортов. Поэтому изучение биологических особенностей и оценка адаптивного потенциала дикорастущих видов, в том числе предковых форм современных сортов, за границами их природных ареалов, а также подбор материала для дальнейшей селекционной работы в частности с представителями рода Paeonia весьма актуальны. 
В отличие от других декоративных культур род пион (Paeonia L.) немногочисленный. Область распространения пионов охватывает обширную территорию. Более 30 видов произрастает в Европе, Средиземноморье, на Кавказе, Восточной и Юго-Восточной Азии, один вид в Северной Африке, два на западе Северной Америки. Большая часть рода представлена травянистыми видами. Обычно это лесные мезофильные растения, среди них редко встречаются ксерофильные степные формы, а в Юго-Восточной Азии древовидные пионы. Многие виды - эндемы, произрастают в горных районах. При изучении ареалов было выявлено два центра высокой видовой их насыщенности: Западный в Средиземноморье и Восточный в Юго-Западном Китае. Изучение ареалов дикорастущих видов является перспективным, как для решения практических, так для теоретических исследований, уточняющих систематику и эволюцию рода (Успенская, 1986; Кузнецова, Васильева, 2011).

Высокая декоративность видов рода Paeonia L. способствуют тому, что они находятся на грани исчезновения и большинство уже занесены в Красную книгу Российской Федерации (2008). Ценнейшей биологической особенностью пионов является их долговечность, способность длительное время произрастать на одном месте без признаков старения и партикуляции. Эта способность, наряду с эффектным цветением, и делает пионы столь популярными, в отличие от тех видов декоративных растений, которым необходимо постоянное возобновление за счет выращивания сеянцев в питомниках. Пионы не требуют укрытия, при правильной агротехнике устойчивы к болезням. Они относятся к корневищным геофитам, почки возобновления которых находятся в почве на разной глубине. Отмечено восстановление растений за счет более глубоко расположенных почек при вымерзании поверхностных такое расположение почек на разной глубине служит приспособлением к перенесению неблагоприятных условий.

На Алтайской опытной станции садоводства (теперь НИИСС им. М. А. Лисавенко) много лет производилось изучение внутривидовой изменчивости декоративных растений Алтая; отобраны виды, перспективные для селекции, в том числе пион степной - P. hybrida Pall. и пион уклоняющийся $P$. anomala L. (Лучник, 1972; Верещагина, 2003). Дикорастущие виды - это исходный материал для получения отдельных генов, которые могут существенно улучшить сорта, например, повысить их декоративность, устойчивость к заболеваниям (Успенская, Мурашев, 2013). В ботаническом саду биологического факультета Московского государственного университета имени М. В. Ломоносова многие десятилетия ведётся селекционная работа по выведению раннецветущих немахровых сортов травянистых пионов, которые можно широко использовать для озеленения, зацветающие на месяц раньше сортовых. В коллекции сада произрастает ряд видов рода Paeonia, привезённых из естественных мест обитания: пион узколистный или тонколистный (P. tenuifolia L.), п. молочноцветковый (P. lactiflora Pall.), п. Млокосевича (P. Mlokosewitschii Lomak.), п. кавказский (P. caucasica = P. kavachensis Aznav.), Maрьин корень (P. anomala L.), п. крымский (P. daurica Andrews), п. Виттмана (P. wittmanniana Hartwiss ex Lindley).

Изучение экологической изменчивости при интродукции даёт широкое поле деятельности для селекционера. Например, у P. tenuifolia L. такие признаки, как ширина листовых сегментов, высота растения зависят от условий произрастания. П. узколистный в естественных условиях обитает в степях, в горах и хорошо адаптируется на дренированных и каменистых местах. В последнее время американский селекционер Клем (Roy Klehm) представил несколько карликовых гибридов п. узколистного. Этот вид легко размножается семенами, образуя многочисленные всходы, которые можно селектировать по высоте, окраске цветка и другим признакам.

Гибридогенные процессы, несомненно, имели место в эволюции рода Paеопia. На современном этапе процесс видообразования продолжается, на что указывают ряд ниже описанных нотовидов. Так, на Кавказе на границе ареалов отмечены находки естественных гибридов - P. majko Ketsch. (P. tenuifolia L. x P. kavachensis Aznav.), а гибрид P. tenuifolia L. x P. daurica Andrews, описанный В. П. Малеевым (1947), - в Крыму. Особое место занимает вид P. mlokosewitchii Lomak. (пион Млокосевича) единственный вид с жёлтыми лепестками и необычной окраской листьев, произрастающий на Кавказе и находящийся на грани исчезновения. Он очень декоративен в стадии плодоношения и широко культивируется в ботанических садах, используется в селекционной работе при выведении новых сортов с жёлтой окраской цветка. Этот вид представляет интерес и в эволюции рода, так как имеет много схо- 
жих признаков с дальневосточным видом P. oreogeton S. Moore. P. mlokosewitchii Lomak. довольно легко скрещивается с другими видами как на коллекционном участке, так в естественных условиях, образуя гибридные формы, например, P. lagodechiana Kem.-Nath. (P. kavachensis Asnav. х P. mlokosewitchii Lomak.) найденный Кемулярией-Натадзе на Кавказе. Позже этот гибрид был описан как P. chameleon Troitsky, который стихийно вырос на коллекционном участке живой флоры Института ботаники Академии наук Грузии (Конспект флоры Кавказа, 2012).

В ботаническом саду МГУ М. С. Успенской созданы весьма декоративные межвидовые гибриды, зарегистрированные в «Госкомиссии при Министерстве сельского хозяйства РФ по испытанию и охране селекционных достижений» (ФГБУ «Госсортокомиссия») как сорта: например, раннецветущий сорт 'Нежность' - гибрид между п. крымским и п. Млокосевича.

В Якутии в районах вечной мерзлоты широко используется для озеленения пион уклоняющийся, или марьин корень, наиболее распространённый в Сибири, на Кольском полуострове, в Средней Азии. В отличие от других видов, он легко размножается семенами в природе. В естественных местах обитания он прекрасно чувствует себя как в мало освещённых, так и на открытых участках. В ботаническом саду МГУ он растёт под пологом ореха маньчжурского и смотрится очень эффектно в период цветения. Этот вид почти никогда не страдает от серой гнили и очень долговечен, при правильном уходе может расти на одном месте от 25 до 50 лет. Мы использовали его в качестве исходного вида при межвидовой гибридизации и получили два сорта: 'Зарница' и 'Александра'.

Среди дикорастущих травянистых видов п. молочноцветковый (P. lactiflora Pall.) стоит особняком, его широко привлекали к селекционному процессу, и в настоящее время зарегистрировано более 85 \% культиваров, используемых в озеленении. Они многоцветковые, морозоустойчивые, засухоустойчивые, устойчивые к патогенным заболеваниям. У пиона молочноцветкового при различных погодных условиях меняется окраска лепестков от розовой до чисто белой. Гибриды, полученные между п. молочноцветковым (P. lactiflora) и п. иноземным (P. peregrina), способствовали появлению сортов: 'Иван Горожанкин', 'Огонёк', зацветающих одними из первых ярко красными цветками. Эти сорта одноцветковые, хотя большинство культиваров п. молочноцветкового - многоцветковые.

Дикорастущие пионы представляют интерес не только как декоративные растения, но и как лекарственные. Не случайно первый пион, описанный Карлом Линнеем в 1763 году, был P. officinalis L. пион лекарственный. Ботанические сады также выявляют виды и формы растений полезные для озеленения, разрабатывают научные основы введения дикорастущих растений в культуру. Проблема использования растений в качестве лекарственного сырья широко разрабатывается как за рубежом, так и в нашей стране. Особый интерес представляют экологически чистые растения, способные оказывать разнообразное воздействие на организм. Так, в медицинской практике широко используется настой марьиного корня в качестве успокаивающегося средства, бессоннице, эпилепсии. На биологическом факультете МГУ имени М. В. Ломоносова в лаборатории защитных систем крови имени Б. А. Кудряшова были исследованы экологически чистые виды, произрастающие в ботаническом саду биофака МГУ: $P$. anomala и P. lactiflora. Результаты исследований показали, что экстракты из корней этих растений обладают антикоагулянтным и фибринолитическим свойствами, способствуют предотвращению тромбообразования (Ляпина и др., 2017). Наш вклад в развитие данной области науки заключается, во-первых, в доказательстве сходства гепариноподобных низкомолекулярных антикоагулянтов растительного происхождения из пионов и низкомолекулярного гепарина животного происхождения во-вторых, в представлении свидетельств их профилактического и терапевтического действия на экспериментальных моделях метаболического синдрома, сахарного диабета и дисфункции эндотелия, 6 -третьих, в установлении лечебных доз антикоагулянтных гепариноподобных соединений растительного происхождения.

Использование освоенных технологий выращивания растительного материала дает возможность широко интродуцировать, и сохранять уникальный генофонд, а также создавать сырьевые базы в различных регионах России и сопредельных странах. Например, марьин корень и п. молочноцветковый неприхотливы к климатическим и почвенным условиям, морозоустойчивы, засухоустойчивы, устойчивы к грибным заболеваниям. Они весьма перспективны для широкого введения в культуру, так как обладают высокой семенной продуктивностью, легко размножаются вегетативно: частью корневищ, корнеклубнями, подрезом куста, корневыми черенками, отводками. Хорошо отработана агротехника их 
выращивания. Свежесобранные семена, высаженные в грунт, могут прорасти на следующий год весной (Успенская, 2001).

Одним из этапов интродукции растений является изучение их биологии в новых условиях с целью решения конкретных задач. Традиционными для интродукции методами изучения растений считаются: фенологические наблюдения, экологическая оценка и др., основными критериями которых становится выявление успешности интродукции растений в тех или иных, несвойственных исследуемым видам и сортам условиях (Нухимовский, Нухимовская, 1978). К современным направлениям изучения растений при интродукции можно отнести разрабатываемые нами комплексные исследования морфобиологических признаков (Барыкина, 1979; Ефимов, 2014) и органогенеза растений для решения теоретических и прикладных задач широкого диапазона (Мурашев, 2004; Комина, и др., 2015).

Изучение биологии развития растений, органогенеза их почек имеет важное теоретическое и прикладное значение, особенно в том случае, когда объектами исследований являются хозяйственно ценные виды, формы и сорта. У пионов, относящихся к декоративным многолетникам, зачаточные структуры цветка закладываются осенью, а цветение происходит весной или в начале лета следующего года. Цветочная продуктивность и декоративный эффект растений из этой группы во многом зависят от степени сформированности зачаточных органов цветка в подземных почках, уходящих в зимовку. Как виды, так сорта пионов относятся к растениям с очень длительным периодом внутрипочечного (эмбрионального) развития побега, у взрослого растения от заложения почки в пазухе чешуи материнской почки до образования в ней зачатка цветущего побега будущего года проходит не менее двух лет, а иногда и более. На одном и том же растении пиона всегда находятся разновозрастные почки, обеспечивающие возобновление побегов. Это спящие почки - мелкие, располагающиеся в пазухах нижних покровных чешуй в базальной части побегов. Они пробуждаются только при ранении корневища, делении растения, удалении активных почек. Это резервные почки, формирующиеся в пазухах самых верхних покровных чешуй, при прорастании побега весной чаще всего они отмирают. А еще почки возобновления закладываются в пазухах срединных покровных чешуй, из которых в дальнейшем разовьются побеги (Успенская, 2001, 2017; Успенская и др., 2016).

При интродукции хозяйственно ценных растений в условия продолжительных и суровых зим континентального и умеренно континентального климата основным критерием отбора является зимостойкость, под которой понимается способность интродуцентов противостоять комплексному воздействию факторов внешней среды на протяжении зимнего и ранневесеннего периодов. Морфофизиологические исследования зимующих почек растений дают ценную информацию об адаптационных возможностях вводимых в культуру растений, а также характеризуют их ритмы роста и развития. Осенью, в конце вегетации, зачаточный побег будущего года в почке видов и сортов пионов сформирован уже полностью, включая цветок, который характеризуется разной степенью дифференциации меристемы преимущественно в пределах V этапа органогенеза, т.е. наблюдается образование и формирование частей цветков: покровных органов, тычиночных бугорков и зачатка пестика. Отмечается начало дифференциации тычиночного бугорка на тычиночную нить и пыльник. Завершается V этап возникновением в пыльниках спорогенной ткани, состоящей из археспориальных клеток. Учитывая способность видов пионов как рано отрастающих и рано зацветающих растений, развиваться при относительно невысоких положительных температурах, дифференциация конуса нарастания может продолжаться осенью до момента промерзания почвы на глубину, на которой находятся почки возобновления, а затем продолжаться весной, задолго до отрастания побегов и появления их на поверхности почвы (Кузнецова, Васильева, 2011; Успенская, 2001; Успенская и др., 2016).

Весной, после выхода из зимнего периода покоя, в развитии генеративных почек проявляется видоспецифичность, выраженная в скорости ростовых процессов и изменении морфометрических показателей, что тесным образом связано с погодными условиями, и в первую очередь, с накоплением сумм эффективных и активных температур.

Наиболее дифференцированными в предзимье и в самом начале вегетационного периода оказались генеративные почки сортов с простыми не махровыми цветками (имеющие полноценные пестики и тычинки) и зацветающие в более ранние сроки. Наименее дифференцированными оказываются генеративные почки сортов с махровыми цветками, имеющие средние, среднепоздние и поздние сроки 
цветения. Таким образом, дифференциация зимующих почек возобновления и их состояние в ранневесенний период у видов и сортов пионов достаточно чётко отражают дальнейшие ритмы цветения и позволяют прогнозировать последовательность зацветания. Темпы развития видов сохраняются в последующем вегетационном периоде: более развитые в предзимнем состоянии почки на следующий год зацветают раньше. Размер почек не коррелирует с этапом органогенеза, на котором находится почка возобновления в предзимье. Например, при отрастании весной P. tenuifolia с наиболее мелкими почками опережает вид с самыми крупными зимующими почками $P$. anomala.

После длительного зимнего сезона и последующей значительной части весеннего периода, в течение которой постепенно тает снеговой покров, зрительное восприятие человека настроено на поиск первых ранневесенних цветов и отрастающих побегов. Пионы относятся к числу не просто рано отрастающих декоративных многолетников. Большинство видов пионов, в отличие от сортов, практически через несколько дней после отрастания разворачивает листовые пластинки оригинальной формы и расцветки. Именно в коллекции видовых пионов в этот период привлекают внимание посетителей желтовато-зеленые тусклые молодые листья P. obovata, ярко-зелёные, практически нитевидные сегменты сложных листьев P. tenuifolia, темно-зелёные, промежуточные, по сравнению с двумя предыдущими видами, по степени рассечённости листья P. hybrida (Кузнецова, Васильева, 2011).

Ландшафтные дизайнеры оперируют цветом и формой в пространственно-временном континууме, соответственно, наряду с окраской цветков, такие биологические особенности, как феноритмотип и различные морфологические признаки дикорастущих декоративных растений могут использоваться в оригинальных приемах и средствах композиции.

Таким образом, разновременное весеннее отрастание и разнообразие побегов, последовательное зацветание различных видов и сортов пиона, сохранение привлекательности посадок даже в период плодоношения позволяют создавать красочные многолетние экспозиции с продолжительным цветением и длительной декоративностью успешно вписывающиеся в урбанофитоценозы различных регионов России.

\section{Заключение}

Вопросы адаптивного растениеводства актуальны в нашей стране, где почвенно-климатические и погодные условия ограничивают разнообразие возделываемых цветочных культур. Интродукция видов пионов перспективна в условиях ЦРНЗ и создает возможность не только сохранять в коллекции редкие и декоративные виды, но и получать посадочный материал.

Комплексная оценка морфогенеза видов и сортов создает фундамент для определения перспективности использования диких представителей рода Paeonia L. в декоративном садоводстве и селекции, а также как источника фармацевтического сырья и для разработки наиболее успешных приемов агротехники.

Дикие пионы представляют большую ценность и для селекционной практики, особенно, при получении сортов раннего цветения. Для этого из коллекционного фонда выделены наиболее перспективные для скрещивания виды: P. lactiflora, P. tenuifolia, P. anomala, P. mlokosewitchii.

Создание нового сорта пионов - сложный процесс, включающий ряд этапов (разработка модели будущего сорта, подбор пар для скрещивания, выращивание сеянцев, их изучение, размножение нового сорта). Заключительным этапом является подготовка пакета документации о признании прав на сорт и передача его в Государственную службу по охране прав на сорта растений. От скрещивания родительской пары до регистрации нового сорта пионов проходит, как правило, 10-15 лет.

\section{ЛИТЕРАТУРА}

Барыкина Р. П. Жизненные формы пионов и возможные пути их структурной эволюции // Вестн. Моск. ун-та. Сер. 16. Биология, 1979. - № 2. - С. 14-26.

Верещагина И. В. Дикорастущие пионы Алтая. - Барнаул: Изд-во Алт. ун-та, 2003. - 229 с.

$\boldsymbol{E} \boldsymbol{\phi и м о в} \boldsymbol{C}$. B. Комплексное изучение и оценка морфологических признаков пиона (Paeоnia L.) при интродукции // Ученые записки Таврического национального университета имени В. И. Вернадского, 2014. - Серия «Биология, химия». - Т. 27(66) - № 5. - С. 47 - 52. 
Комина О. В., Васильева О. Ю., Черемисина А. В. Изучение органогенеза растений в высшей и средней школе // Сибирский педагогический журнал, 2015. - № 4. - С. 44-48.

Конспект флоры Кавказа: в 3 томах. / Отв. ред. А. Л. Тахтаджян. Т. 3(2). - СПб.-М.: Тов-во научн. изд. КМК, 2012. $-623 \mathrm{c}$.

Красная книга Российской Федерации. (Растения и грибы). Сост. Р. В. Камелин и др. — М.: Тов-во научн. изданий КМК, 2008. - 855 с.

Кузнецова О. В., Васильева О. Ю. Видовые пионы в Сибири // Цветоводство, 2011. - Вып. 4. - С. 13-15.

Лучник 3. И. Гибриды сибирских пионов // Растения природной флоры Сибири для зеленого строительства. Новосибирск, 1972. - С. 256-264.

Ляпина М. Г., Успенская М. С., Мурашев В. В., Ляпина Л. А. Пионы целители. - М.: Лесная страна, 2017. $100 \mathrm{c}$.

Малеев В. П. Сем. Ranunculaceae Juss. I. Paeonia L. // Е. В. Вульф. Флора Крыма. - Т. 2, вып. 1. - M., 1947. C. $173-177$.

Мурашев В. В. Биология развития растений в Московском университете // Бюл. Моск. об-ва испытателей природы. Отд. биолог - М.: изд-во Моск. ун-та, 2004. - Т. 4. - № 6. - С. 44-50.

Нухимовский Е. Л., Нухимовская Ю. Д. Экологическая морфология некоторых лекарственных растений в естественных условиях их произрастания. Сообщ. 5. Paeonia anomala L. // Растит. ресурсы, 1978. - T. 14 - вып. 1. - С. 347-355.

Успенская M. С. Определение видов рода Paeonia L. флоры CССР в фазе плодоношения // Бюл. Моск. о-ва испытателей природы. Отд. биол., 1986. - Т. 91, вып.3. - С. 102-107.

Успенская М. С. Пионы. - М.: Фитон +, 2001. - 207 с.

Успенская М. С. Древовидные пионы. Коллекция Ботанического сада МГУ имени М. В. Ломоносова. - М.: ПЕНТА, 2017. - 144 c.

Успенская М. С., Мурашев В. В. Селекция, размножение и перспективы интродукции древовидных пионов в России и СНГ // Цветоводство: традиции и современность. - Белгород, 2013. - С. 198-201.

Успенская М. С., Мурашев В. В., Криницына А. А. Древовидные пионы в ботаническом саду МГУ / Под ред. В. В. Мурашева. - М.: Лесная страна, 2016. - 104 с. 